\title{
Identification of the Chemical Compound of Essential Oil from Ketumbar (Coriandrum sativum L.) Leaves with Gc-Ms
}

\author{
Kasta Gurning ${ }^{1, *}$, Iksen ${ }^{1}$, Helen Anjelina Simanjuntak ${ }^{1}$, Hermawan Purba ${ }^{1,2}$
}

Kasta Gurning ${ }^{1, *}$, Iksen', Helen Anjelina Simanjuntak' Hermawan Purba ${ }^{1,2}$

'Department of Pharmacy, Sekolah Tinggi Ilmu Kesehatan Senior Medan, Medan-20141, INDONESIA.

${ }^{2}$ Department of Chemistry, Faculty of Mathematics and Natural Science, Universitas Sumatera Utara, Medan-20155 INDONESIA.

\section{Correspondence}

\section{Kasta Gurning}

Department of Pharmacy, Sekolah Tinggi Ilmu Kesehatan Senior Medan, Medan-20141, INDONESIA.

Phone no: +6285296522212

E-mail: kastagurning@gmail.com

History

- Submission Date: 19-04-2020

- Review completed: 20-05-2020;

- Accepted Date: 10-06-2020.

DOI : 10.5530/pj.2020.12.144

Article Available online

http://www.phcogj.com/v12/i5

Copyright

(C) 2020 Phcogj.Com. This is an openaccess article distributed under the terms of the Creative Commons Attribution 4.0 International license.

\section{ABSTRACT}

Introduction: Coriandrum sativum L. leaves are plants used as a cooking spice that has a distinctive aroma. Various components of bioactive compounds are known from various parts of this plant, but the components of the bioactive compounds of essential oils from the leaves have never been reported. Objective: This research was designed to analyze the components of bioactive compounds contained in the essential oil of $C$. sativum leaves using a modified simple distillation tool. Method: $C$. sativum leaves essential oil component analysis with GC-MS (Shimadzu QP-2010 Plus). Results: Analysis GC-MS of the content of the bioactive compounds of essential oils contained various bioactive compounds. The dominant bioactive compounds are 2-Decen-1-ol (17.01\%), 9-Octadecenal (9.59\%), 1-Decanol (8.20\%), Dotriacontane (4.40\%), and Tetrapentacosan (3.68\%). Conclusion: The results of the research showed that there were various bioactive compound contents from the essential oil of $C$. sativum leaves and it was important to test the activity of each component of the bioactive compound as an important recommendation for pharmaceutical natural ingredients.

Key words: Bioactive compounds, Coriandrum sativum, Distillation, Essential oil and GC-MS.

\section{INTRODUCTION}

Ketumbar (Coriandrum sativum $\mathrm{L}$.) is a plant that is widely used as a spice, especially in cooking spices. This plant has a distinctive aroma. The distinctive aroma that is owned because this plant contains essential oils. ${ }^{1}$ Phytochemical screening results of coriander seeds have diverse secondary metabolites, including steroids, flavonoids, saponins, tannins, coumarin, ${ }^{2}$ volatile compounds ${ }^{3}$ and coriander leaves are contain phenolic acid, poliyphenols, glycosides, saponins, flavonoids and tannins. ${ }^{4,5}$ These coriander plants have diverse biology activities including antioxidant, ${ }^{6}$ antimicrobial, hypoglycemic, hypolipidemic, anxiolytic, analgesic, anti-inflammatory, anti-convulsant ${ }^{3}$ and anti-cancer activities and gastrointestinal, antiinflammatory, antiseptic, tranquilizing nervous system, lipolytic and miorelaksan, rerigeran, tonic, dieretic, rheumatic, neuralgia, and flatulence ${ }^{7}$ and antimicrobials. ${ }^{8}$ This study aims to characterize, isolate essential oils and analyze the content of bioactive compounds of $C$. sativum leaves using Gas Chromatography-Mass Spectrocopy (GC-MS).

\section{MATERIALS AND METHODS}

Preparation sample

Fresh of ketumbar (C. sativum) leaves were obtained from the Berastagi area, Karo district, North Sumatera, Indonesia. The C. sativum leaves is authorized by the Indonesian scientific institution: Biology Research Center (3533/MEDA/2019). Samples are cleaned in running water, drained, and dried in open spaces which avoid direct contact with sunlight. The dried sample was mashed using a blender to obtain the simplicia powder of $C$. sativum leaves.

Preparation of isolation essential oil of $C$. sativum leaves

Isolation of essential oils of simplicia of C. sativum leaves was carried out by means of modified distillation (Figure 1). Simplisia C. sativum leaves are put into a round pumpkin, plus boiling stones and distilled water to taste. The distillation process is carried out for 1-2 days per $500 \mathrm{~g}$ simplicia of $C$.

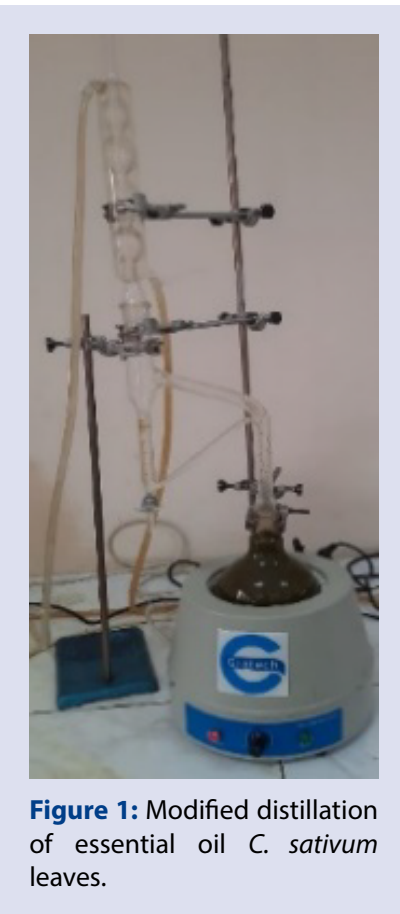

Cite this article: Gurning K, Iksen, Simanjuntak HA, Purba H. Identification of the Chemical Compound of Essential Oil from Ketumbar (Coriandrum sativum L.) Leaves with Gc-Ms. Pharmacogn J. 2020;12(5):1019-23. 
sativum leaves. The isolated essential oil was separated from the water mixture and stored in a vial bottle. The residue of water was removed by adding anhydrous $\mathrm{Na}_{2} \mathrm{SO}_{4}$, to obtain water-free essential oil. The essential oil obtained was determined by the yield.

\section{GC-MS (Gas Chromatography-Mass Spectrometry) analysis}

Investigation of essential oil chemical compounds was carried out using Gas Chromatography-Mass Spectrometry equipment (Shimadzu QP-2010 Plus) with the condition of the tool specifications as follows: Rtx-5MS capillary column type, column length of 30 meters, column diameter of $0.25 \mathrm{~mm}$, column thickness of $0.25 \mu \mathrm{m}$, injector temperature of $300^{\circ} \mathrm{C}$, pressure of $53 \mathrm{kPa}$, carrier gas He with flow rate of $0.99 \mathrm{ml} / \mathrm{min}$, methyl silicon the stationary phase, temperature of the programmed column (temperature programming) with an initial temperature of $50^{\circ} \mathrm{C}$, then slowly increased with a rate of increase of $10^{\circ} \mathrm{C}$ until reaching the final temperature of $300^{\circ} \mathrm{C}$ and maintained. The volume of essential oils injected $5 \mu$, the results were compared using the Wiley spectral library database program. ${ }^{9}$

\section{RESULTS AND DISCUSSION}

\section{Isolation of essential oil C. sativum leaves and GC-MS analysis}

The results of isolation of C. sativum essential oil with a yield of $0.2 \%$ with a reddish yellow color, produce a distinctive aroma (Figure 2). Essential oils from GC-MS analysis obtained 35 peaks with different retention times, eighteen compounds identified with six compounds identified repeatedly (Figure 3 and Table 1).

Components of bioactive compounds found essential oils in C. sativum leaves have been reported to have diverse potential activities. Potential activities of essential oils include antibacterial, antifungal, Antioxidant, Anti Inflammatory, ${ }^{8,9}$ irritant to mouth, throat and stomach, ${ }^{10}$ antimicrobial, antifibrinolytic, hemolytic, lubricant, nematicide, antialopecic, and hypocholesterolemic. ${ }^{11}$ The results of analysis of essential oils of $C$. sativum leaves with the 5 biggest components are 2-Decen-1-ol $\left(\mathrm{t}_{\mathrm{R}} 14.298 \mathrm{~min} ; \mathrm{C}_{10} \mathrm{H}_{20} \mathrm{O}\right.$ and peak area 17.01\%), 9-Octadecenal $\left(t_{R} 16.860 \mathrm{~min} ; \mathrm{C}_{18} \mathrm{H}_{34} \mathrm{O}\right.$ and peak area
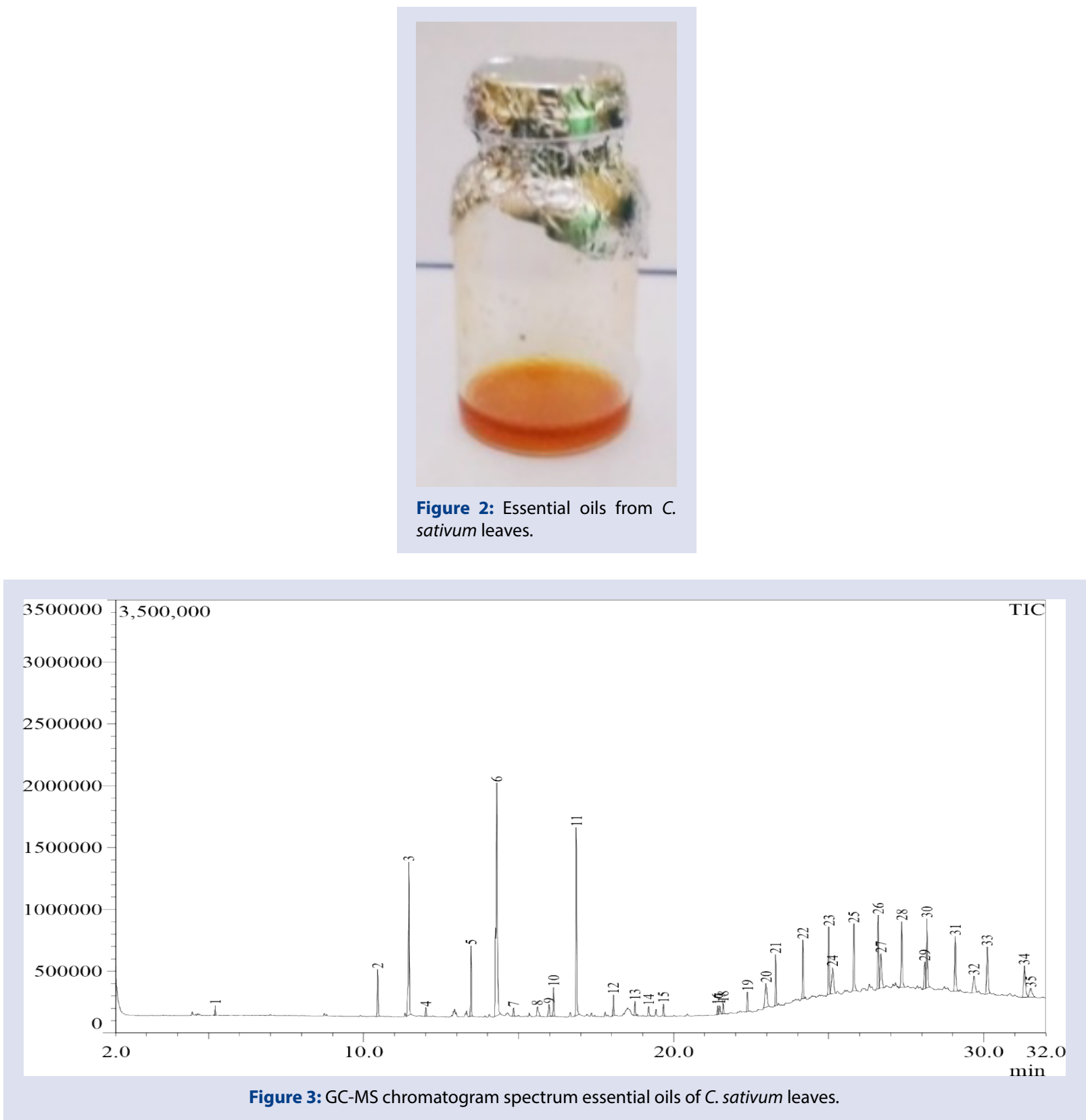
Table 1: Identification essential oil of C. sativum leaves compound using GC-MS.

\begin{tabular}{|c|c|c|c|c|c|}
\hline $\begin{array}{l}\text { No. } \\
\text { Peak }\end{array}$ & Component name & $\begin{array}{l}\text { Retention time/ } t_{R} \\
(\min )\end{array}$ & Molecular formula & Molecular weight (g/mol) & $\begin{array}{c}\text { Peak Area } \\
(\%)\end{array}$ \\
\hline 1 & Nonane & 5.214 & $\mathrm{C}_{9} \mathrm{H}_{20}$ & 128 & 0.42 \\
\hline 2 & Decanal & 10.458 & $\mathrm{C}_{10} \mathrm{H}_{20} \mathrm{O}$ & 156 & 2.14 \\
\hline 3 & 1-Decanol & 11.459 & $\mathrm{C}_{10} \mathrm{H}_{22} \mathrm{O}$ & 158 & 8.20 \\
\hline 4 & Undecanal & 12.008 & $\mathrm{C}_{11} \mathrm{H}_{22} \mathrm{O}$ & 170 & 0.43 \\
\hline 5 & Tetradecanal & 13.462 & $\mathrm{C}_{14} \mathrm{H}_{28} \mathrm{O}$ & 212 & 3.38 \\
\hline 7 & Tridecanal & 14.833 & $\mathrm{C}_{13} \mathrm{H}_{26} \mathrm{O}$ & 198 & 0.45 \\
\hline 8 & Octadecanal & 15.608 & $\mathrm{C}_{18} \mathrm{H}_{36} \mathrm{O}$ & 268 & 0.84 \\
\hline 9 & 9-Octadecenal & 15.984 & $\mathrm{C}_{18} \mathrm{H}_{34} \mathrm{O}$ & 266 & 0.79 \\
\hline 10 & Tetradecanal & 16.126 & $\mathrm{C}_{14} \mathrm{H}_{28} \mathrm{O}$ & 212 & 1.35 \\
\hline 11 & 9-Octadecenal & 16.860 & $\mathrm{C}_{18} \mathrm{H}_{34} \mathrm{O}$ & 266 & 9.59 \\
\hline 12 & 9-Octadecenal & 18.055 & $\mathrm{C}_{18} \mathrm{H}_{34} \mathrm{O}$ & 266 & 1.10 \\
\hline 14 & 9-Octadecenal & 19.196 & $\mathrm{C}_{18} \mathrm{H}_{34} \mathrm{O}$ & 266 & 0.51 \\
\hline 15 & Hexadecanoic acid & 19.674 & $\mathrm{C}_{17} \mathrm{H}_{34} \mathrm{O}_{2}$ & 270 & 0.59 \\
\hline 16 & $9,12,15$-Octadecatrienoic acid & 21.489 & $\mathrm{C}_{19} \mathrm{H}_{32} \mathrm{O}_{2}$ & 292 & 0.52 \\
\hline 17 & $9,12,15$-Octadecatrienoic acid & 21.489 & $\mathrm{C}_{19} \mathrm{H}_{32} \mathrm{O}_{2}$ & 292 & 0.49 \\
\hline 18 & Neophytadiene & 21.598 & $\mathrm{C}_{20} \mathrm{H}_{38}$ & 278 & 0.60 \\
\hline 19 & Pentadecane & 22.380 & $\mathrm{C}_{21} \mathrm{H}_{44}$ & 296 & 0.99 \\
\hline 20 & Dotriacontane & 22.979 & $\mathrm{C}_{32} \mathrm{H}_{66}$ & 450 & 2.77 \\
\hline 21 & Hexacosane & 23.291 & $\mathrm{C}_{26} \mathrm{H}_{54}$ & 366 & 2.48 \\
\hline 22 & Tetracontane & 24.165 & $\mathrm{C}_{40} \mathrm{H}_{82}$ & 562 & 2.94 \\
\hline 23 & Dotriacontane & 25.004 & $\mathrm{C}_{32} \mathrm{H}_{66}$ & 450 & 3.61 \\
\hline 24 & Dotriacontane & 25.122 & $\mathrm{C}_{32} \mathrm{H}_{66}$ & 450 & 2.95 \\
\hline 25 & Dotriacontane & 25.813 & $\mathrm{C}_{32} \mathrm{H}_{66}$ & 450 & 3.76 \\
\hline 26 & Dotriacontane & 26.592 & $\mathrm{C}_{32} \mathrm{H}_{66}$ & 450 & 3.92 \\
\hline 27 & Dotriacontane & 26.683 & $\mathrm{C}_{32} \mathrm{H}_{66}$ & 450 & 3.13 \\
\hline 29 & Tetrapentacosan & 28.098 & $\mathrm{C}_{54} \mathrm{H}_{110}$ & 758 & 2.22 \\
\hline 30 & Dotriacontane & 28.169 & $\mathrm{C}_{32} \mathrm{H}_{66}$ & 450 & 4.40 \\
\hline 31 & Dotriacontane & 29.079 & $\mathrm{C}_{32} \mathrm{H}_{66}$ & 450 & 3.89 \\
\hline 32 & Tetrapentacosan & 29.679 & $\mathrm{C}_{54} \mathrm{H}_{110}$ & 758 & 1.98 \\
\hline 33 & Tetrapentacosan & 30.112 & $\mathrm{C}_{54} \mathrm{H}_{110}$ & 758 & 3.68 \\
\hline 34 & Tetrapentacosan & 31.313 & $\mathrm{C}_{54} \mathrm{H}_{110}$ & 758 & 3.06 \\
\hline 35 & Tetrapentacosan & 31.511 & $\mathrm{C}_{54} \mathrm{H}_{110}$ & 758 & 1.32 \\
\hline
\end{tabular}

9.59\%), 1 -Decanol ( $t_{\mathrm{p}} 11.459 \mathrm{~min} ; \mathrm{C}_{10} \mathrm{H}_{22} \mathrm{O}$ and peak area $8.20 \%$ ), Dotriacontane ( $\mathrm{t}_{\mathrm{R}} 28.353 \mathrm{~min} ; \mathrm{C}_{32} \mathrm{H}_{66}$ and peak area 4.40\%), and Tetrapentacosan $\left(\mathrm{t}_{\mathrm{R}} 30.112 \mathrm{~min} ; \mathrm{C}_{54} \mathrm{H}_{11} \mathrm{O}\right.$ and peak area $\left.3.68 \%\right)$.

\section{CONCLUSION}

The components of the bioactive compounds contained essential oils in C. sativum leaves after being analyzed by GC-MS were very diverse. This strongly supports the use of C. sativum leaves for various treatments and traditional cooking spices. An ongoing evaluation needs to be carried out to determine for certain the potential activities of each component as important information on phytopharmacy.

\section{ACKNOWLEDGMENT}

The author would like to thank Hutri Simamora for helping with the research and the Sekolah Tinggi Ilmu Kesehatan Senior Medan for providing laboratory.

\section{REFERENCES}

1. Mandal S, Mandal M. Coriander (Coriandrum sativum L.) essential oil: Chemistry and biological activity. Asian Pacific Journal of Tropical Biomedicine. 2015;5(6):421-8.
2. Ahmed EHJ, Abadi RSM, Mohammed AMA. Phytochemical screening, chemical composition and antioxidant activity of seeds essential oil of Coriandrum sativum L. from the Sudan. International Journal of Herbal Medicine. 2018;6(1):1-4.

3. Laribi B, kouki K, M'Hamdi M, Bettaieb T. Coriander (Coriandrum sativum L.) and its bioactive constituents. Fitoterapia. 2015;103:9-26.

4. Sahib NG, Anwar F, Gilani A-H, Hamid AA, Saari N, Alkharfy KM. Coriander (Coriandrum sativum L.): A Potential Source of High-Value Components for Functional Foods and Nutraceuticals- A Review. Phytotherapy Research. $2012 ; 1-18$

5. Paul N, Sen SK, Karim mFB, Hasan N, Faruque A. Phytochemical and biological investigations of Coriandrum sativum (Cilantro) leaves. International Journal of Innovative Pharmaceutical Sciences and Risearch. 2013;1(1):170-84.

6. Siregar TM, Cayana $\mathrm{AH}$, gunawan RJ. Characteristics and Free Radical Scavenging Activity of Zinc Oxide ( $\mathrm{ZnO}$ ) Nanoparticles Derive d from Extract of Coriander (Coriandrum sativum L.). Reaktor. 17(3):144-50.

7. Chahal KK, Singh R, Kumar A, Bhardwaj U. Chemical composition and biological activity of Coriandrum sativum L.: A review. Indian Journal of Natural Products and Resources. 2017;8(3):193-203.

8. Patel K, Vakilwala M. Phytochemical study and bioactivity of solven extracts on Coriandrum sativum. International Journal of Advances Research in Biological Sciences. 2016;3(5):193-9.

9. Hasan MM, Mahmud MRA, Islam MG. GC-MS analysis of bio-active compounds in ethanol extract of Putranjiva roxburghii Wall. fruit peel. Pharmacognosy Journal. 2019;11(1):146-9. 
10. Arora S, Kumar G, Meena S. GC-MS analysis of bioactive compounds from the whole plant hexane extract of Cenchrus Setigerus VAHL. Pharma Science Monitor. 2017;8(4):137-46.

11. Cornara L, Biagi M, Xiao J, Burlando B. Therapeutic properties of bioactive compounds from different honeybee products. Frontiers in Pharmacology. 2017;8(412):1-20.
12. Chhikara N, Kour R, Jaglan S, Gupta P, Gat Y, Panghal A. Citrus medica: Nutritional, phytochemical composition and health benefits-a review. Food \& Function. 2018;9(4):1978-92.

13. Sharmila M, Rajeswari M, Jayashree I, Geetha DH. GC-MS analysis of bioactive compounds of Amarantus polygonoides Linn. (Amaranthaceae). International Journal of Applied and Advanced Scientific Research. 2016;1(1):174-80.

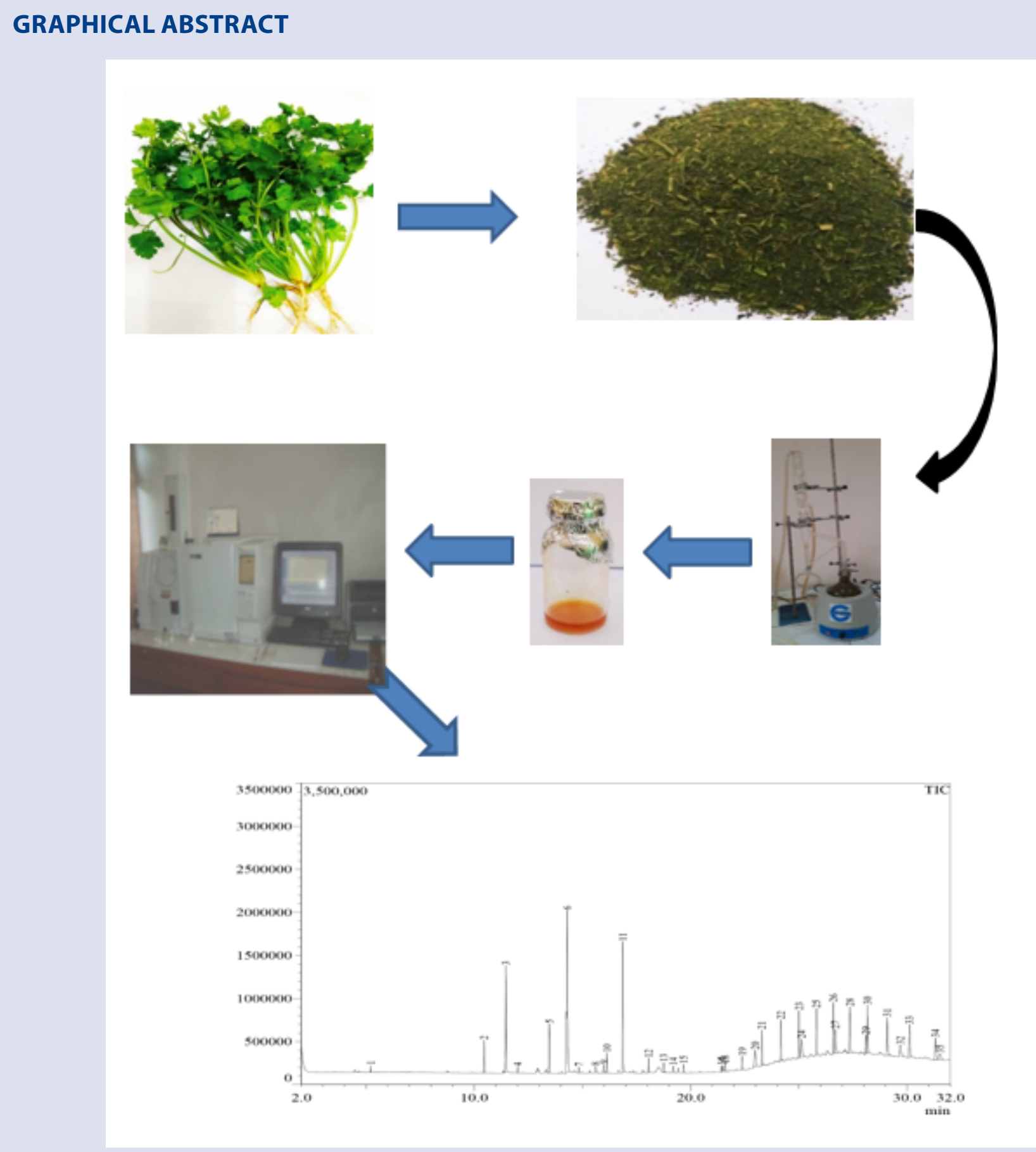




\section{ABOUT AUTHORS}

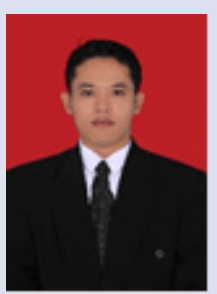

Kasta Gurning is a lecturer in the field of research and focus on study about organic chemistry, natural chemical chemistry, natural medicinal compounds and their combination.

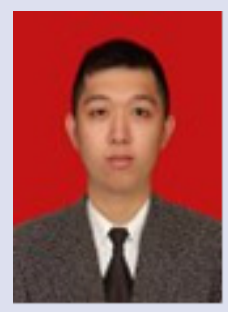

Iksen is a lecturer in the field of research and focus on study about pharmacy, pharmacology and toxicology. $\mathrm{He}$ is currently honored to continue his doctoral program in pharmacology at Chulalongkorn University.

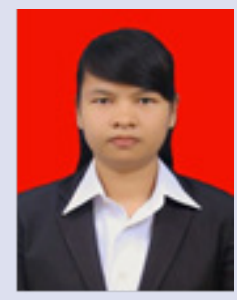

Helen Anjelina Simanjuntak is a lecturer in the field of research and focus on study about biology, microlobiology, pharmaceutical botanist and its combination for the discovery of drug compounds.

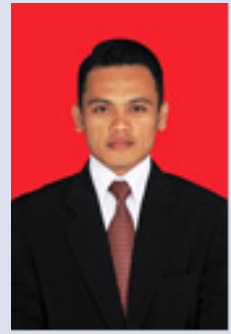

Hermawan Purba is a lecturer in the field of research and focus on study about analytical chemistry, natural product, and analytical instrumentation. He is currently honored to continue his doctoral program in Mathematics and Natural Sains Universitas Sumatera Utara.

Cite this article: Gurning K, Iksen, Simanjuntak HA, Purba H. Identification of the Chemical Compound of Essential Oil from Ketumbar (Coriandrum sativum L.) Leaves with Gc-Ms. Pharmacogn J. 2020;12(5):1019-23. 